\title{
Substrate specificity of nine NAD+-dependent alcohol dehydrogenases in Aspergillus nidulans
}

\author{
Heather M. Sealy-Lewis and Valerie Fairhurst \\ Author for correspondence: Heather M. Sealy-Lewis. Tel: +441482 465970. Fax: +441482465458. \\ e-mail: H.M.Sealy-Lewis@applied-biology.hull.ac.uk
}

Department of Applied Biology, University of Hull, Hull HU6 7RX, UK

\begin{abstract}
In Aspergillus nidulans three alcohol dehydrogenases (ADHs) have been described. ADHI is induced by ethanol and is the physiological enzyme of ethanol utilization, ADHII has not been attributed a function but is repressed by ethanol. The ALCR regulatory protein acts positively to induce ADHI, and negatively in its control of ADHII. ADHIII is specifically induced by anaerobic stress. We have characterized the substrate specificity of these three enzymes by looking at their staining profile on polyacrylamide gels with a range of alcohols. In addition to these enzymes we have observed six other NAD+dependent ADHs, two of which, propan-2-ol dehydrogenase and pentan-2-ol dehydrogenase, share similar control with ADHII. The inducibility of these enzymes with some alcohols has also been investigated. The profile of ADHs with NADP+ ${ }^{+}$as an electron acceptor is also reported.
\end{abstract}

Keywords: alcohol dehydrogenases, Aspergillus nidulans

\section{INTRODUCTION}

Aspergillus nidulans is able to grow on ethanol as a carbon source. The ability to utilize ethanol is dependent upon two structural genes, alc $A$, encoding alcohol dehydrogenase $\mathrm{I}(\mathrm{ADHI})$ and ald $A$, encoding aldehyde dehydrogenase. alc $A$, ald $A$ and alcR (the regulatory gene) are under the positive control of ALCR. alc $A$ and alcR are clustered on linkage group VII, while ald $A$ maps on linkage group VIII (Pateman et al., 1983; Sealy-Lewis \& Lockington, 1984). Growth of $A$. nidulans on other carbon sources (such as propan-2-ol and butan-2-ol) is poor while many alcohols (such as propan-1-ol) are toxic to the organism. Although many alcohols are poor substrates for the growth of the organism, many of them in addition to ethanol are good inducers of ADHI (Creaser et al., 1985; Felenbok \& Sealy-Lewis, 1994).

Two other $\mathrm{ADH}$ s have been described in $A$. nidulans. ADHII (structural gene, alcB), unlike ADHI, is repressed by ethanol in the growth medium (Sealy-Lewis \& Lockington, 1984), whereas ADHIII (structural gene, alc $C$ ) is produced under conditions of anaerobic stress (Kelly et al., 1990).

In an alcR 125 mutant strain that carries a putative nonsense mutation in alcR (Roberts et al., 1979), alc $A$ and ald $A$ are non-inducible, while ADHII is derepressed in

Abbreviations: ADH, alcohol dehydrogenase; glycerol $D H, N^{\prime} D^{+}$-dependent glycerol dehydrogenase. the presence of ethanol. This led to the proposal that alcB is under the negative control of ALCR. The physiological function of ADHII in the cell is not known. alc $A$, ald $A$, alc $\mathrm{R}$ and alc $B$ are subject to carbon catabolite repression (Bailey \& Arst, 1975; Pateman et al., 1983; Sealy-Lewis \& Lockington, 1984), and in the case of alc $A$, ald $A$ and alc $R$ this has been shown to be mediated by CREA (Lockington et al., 1987; Felenbok et al., 1989). ADHIII is post-transcriptionally regulated and is thought to be involved in the survival of the organism during periods of waterlogging. Neither ALCR nor CREA are involved in the regulation of ADHIII (structural gene, alc $C$ ) (Kelly et al., 1990). alc $A$, ald $A$, alc $\mathrm{R}$ and alc $C$ have been cloned and sequenced (Gwynne et al., 1987; Pickett et al., 1987; Felenbok et al., 1988; Kulmburg et al., 1991; McKnight $e t$ al., 1985), and more recently alcB has been cloned and sequenced (G. Hunter, I. G. Jones \& H. M. Sealy-Lewis, unpublished).

One other enzyme has been characterized that is capable of utilizing ethanol as a substrate, namely $\mathrm{NADP}^{+}-$ dependent glycerol dehydrogenase II (glycerol DHII) which is specifically induced by D-galacturonate (SealyLewis \& Fairhurst, 1992).

The three $\mathrm{NAD}^{+}$-dependent ADHs of $A$. nidulans and the $\mathrm{NADP}^{+}$-dependent glycerol DHII are present under completely different growth conditions in the cell, and moreover they can be visualized as bands of different mobility on native PAGE (Sealy-Lewis \& Lockington, 1984; Kelly et al., 1990; Sealy-Lewis \& Fairhurst, 1992). 
We have studied the substrate specificity of these enzymes by comparing their staining with a range of alcohols in polyacrylamide gels. As well as establishing the substrate specificity of the ethanol dehydrogenases mentioned above we were also able to characterize a number of $\mathrm{NAD}^{+}$-specific and $\mathrm{NADP}^{+}$-specific enzymes that stained with a variety of alcohols. Two enzymes which we have designated propan-2-ol dehydrogenase and pentan-2-ol dehydrogenase are regulated in a similar manner to ADHII, i.e. they are repressed in the presence of ethanol, but are derepressed in the alcR 125 mutant strain.

\section{METHODS}

Strains. The markers not specifically detailed below are described in Clutterbuck (1974). The wild-type strain used was pabaA1 (auxotrophic for $p$-aminobenzoic acid). Strain H444: bi $A 1$; alc $\mathrm{R} 125$ (auxotrophic for biotin and carrying a nonsense mutation in alcR; Roberts et al., 1979). Strain $\mathrm{H} 527$ : paba A1; alX4; sB43; alc $A 527$. alc $A 527$ mutants lack any $\mathrm{ADHI}$ activity (Sealy-Lewis \& Lockington, 1984). Strain H1035: biA1; alcE1; alc500; alcD1. The alcE and alcD mutations confer 100-fold greater ADHII activity than the alc500-containing strain (SealyLewis, 1990). alc500 is a deletion spanning alc $A$ and alcR (Lockington, 1984). The strain used for looking at ADHIII activity was a multi-copy transformant (4-8 copies) of the alc $C$ clone in an amdS plasmid $\mathrm{pANa} 3 \mathrm{Pv}$ in recipient strain $\mathrm{H} 849$ (paba A1; amdS320 amdI18; alc A527 amd A7; Jones \& SealyLewis, 1989).

Culture conditions. Media and supplements were as described by Cove (1966). For growth in liquid medium, strains were grown in appropriately supplemented $1 \%(\mathrm{w} / \mathrm{v})$ glucose medium, $10 \mathrm{mM}$ urea, for $16 \mathrm{~h}$ at $37^{\circ} \mathrm{C}$ in an orbital shaker $(120$ r.p.m.). The mycelium was harvested by filtration and transferred to fresh minimal medium containing either glycerol $(100 \mathrm{mM})$, D-galacturonate $(50 \mathrm{mM})$, D-glucose $(50 \mathrm{mM})$, ethanol (100 mM), propan-2-ol (100 mM), pentan-2-ol (50 mM), or 2,3-butanediol ( $50 \mathrm{mM}$, Sigma, mixture of DL and meso forms), as well as to medium containing no carbon source. After $6 \mathrm{~h}$ incubation the mycelium was harvested by filtration. One of the cultures was transferred to $50 \mathrm{mM}$ glucose for $24 \mathrm{~h}$ under anaerobic conditions. Growth conditions for observing ADHII involved transfer to $0 \cdot 1 \%$ fructose for $6 \mathrm{~h}$ as described above.

Gel electrophoresis. Gel electrophoresis was performed as described by Sealy-Lewis \& Fairhurst (1992). The gel stain was modified from that described for ADH (Sealy-Lewis \& Lockington, 1984). Either $\mathrm{NAD}^{+}$or $\mathrm{NADP}^{+}$was added to $0 \cdot 2 \mathrm{mg} \mathrm{ml}^{-1}$. The following substrates at a final concentration of $100 \mathrm{mM}$ were used: methanol, ethanol, propan-1-ol, propan-2 ol, butan-1-ol, butan-2-ol, isobutanol, pentan-2-ol, allyl alcohol, glycerol, crotyl alcohol, cinnamyl alcohol, threonine, 2,3butanediol, 1,2-propanediol, erythritol, and mannitol. Protein concentration was measured according to the microbiuret method (Goa, 1953) and concentrations of protein from different extracts were equalized before loading onto a gel.

\section{RESULTS}

Glucose-grown mycelium, from a wild-type strain was transferred to a variety of carbon sources and growth conditions designed to express ADHI (ethanol), ADHII $(0 \cdot 1 \%$ fructose), ADHIII (anaerobic conditions), and glycerol DHII (D-galacturonate). Extracts from the mycelium were run on polyacrylamide gels and stained for

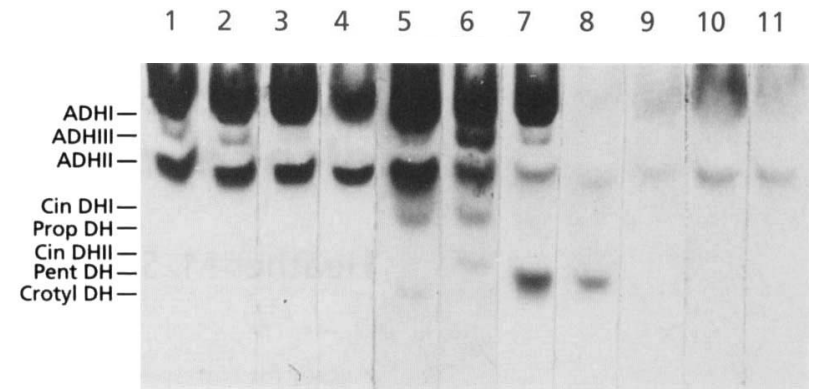

Fig. 1. $A D H$ activity of an extract of the wild-type strain on an activity stained gel. Mycelia were grown for $16 \mathrm{~h}$ at $37^{\circ} \mathrm{C}$ on $1 \%$ glucose and transferred to $50 \mathrm{mM}$ 2,3-butanediol for a further $6 \mathrm{~h}$. Each track was loaded with $40 \mu \mathrm{g}$ protein. The staining solution contained $\mathrm{NAD}^{+}$and a different substrate for each track. Tracks: 1 and 2, isobutanol; 3, butan-1-ol; 4, methanol; 5, crotyl alcohol; 6, cinnamyl alcohol; 7, pentan-2-ol; 8, 2,3-butanediol; 9, no substrate; 10, L-threonine; 11, erythritol. The enzymes are indicated on the left of the gel, and cinnamyl dehydrogenase, propan-2-ol dehydrogenase, and pentan-2-ol dehydrogenase are abbreviated as $\mathrm{Cin} \mathrm{DH}$, Prop $\mathrm{DH}$ and Pent $\mathrm{DH}$, respectively. The propan-2-ol dehydrogenase was visible on the gel stained with pentan-2-ol, but is very faint on the photograph. Its mobility was between that of cinnamyl dehydrogenase I and II. ADHIII was seen optimally after transfer to anaerobic conditions but was sometimes seen after growth at $37^{\circ} \mathrm{C}$ as above because the cultures became anaerobic after prolonged growth (Kelly et al., 1990). This is a representative gel and extracts were grown up more than once and stained with the range of substrates.

activity with the following substrates: methanol, ethanol, propan-1-ol, propan-2-ol, butan-1-ol, butan-2-ol, isobutanol, pentan-2-ol, allyl alcohol, glycerol, crotyl alcohol, cinnamyl alcohol, threonine, 2,3-butanediol, 1,2propanediol, erythritol and mannitol (see Fig. 1 for a representative gel, and Table 1). Either $\mathrm{NAD}^{+}$or $\mathrm{NADP}^{+}$ was used as the electron acceptor. ADHI, ADHII and ADHIII only exhibit activity in the gel stain when $\mathrm{NAD}^{+}$ is present, and glycerol DHII only shows activity with $\mathrm{NADP}^{+}$. When $\mathrm{NADP}^{+}$was used as the electron acceptor with glycerol as the substrate, an activity band additional to glycerol DHII was seen which corresponded to the previously described glycerol DHI (Hondmann et al., 1991; Sealy-Lewis \& Fairhurst, 1992). The latter enzyme is constitutively expressed and was previously shown to have activity with either glycerol or erythritol, but additionally it has some activity with 2,3-butanediol and 1,2-propanediol. Glycerol DHII has a much broader substrate specificity (Sealy-Lewis \& Fairhurst, 1992; Table 1). The only other substrate that showed activity in the gel stain when $\mathrm{NADP}^{+}$was used as an electron acceptor was mannitol and there were three bands visible which were constitutively expressed.

The substrate specificity of ADHI, ADHII and ADHIII is shown in Table 1. These ADHs have a broad spectrum of activity. Of the ADHs, ADHI had the most intense staining with a wide range of alcohols. When staining with $\mathrm{NAD}^{+}$as the electron acceptor, and using a range of substrates, there were a number of bands that did not correspond to the three ADHs (ethanol dehydrogenases). 
Table 1. Substrate specificity of ADHs in A. nidulans

The substrate specificity of the $\mathrm{ADHs}$ was determined by comparing the staining in the presence of substrates (all at $100 \mathrm{mM}$ ) in extracts from cultures grown under the condition where the ADHs are optimally expressed (see Fig. 1). The staining ability is denoted on a scale + to ++++ . The order of the enzymes in the table follows their increasing mobility on polyacrylamide gels. There are three bands that stained only with $\mathrm{NADP}^{+}$and mannitol that were constitutively expressed but are not shown in the table (see text).

\begin{tabular}{|c|c|c|c|c|c|c|c|c|c|c|c|}
\hline \multirow[t]{3}{*}{ Substrate } & \multicolumn{9}{|c|}{$\mathrm{NAD}^{+}$-dependent alcohol dehydrogenases (in order of mobility on gel) } & \multirow{2}{*}{\multicolumn{2}{|c|}{$\begin{array}{c}\text { NADP }^{+} \text {-dependent } \\
\text { glycerol } \\
\text { dehydrogenases }\end{array}$}} \\
\hline & \multirow[t]{2}{*}{ ADHI } & \multirow[t]{2}{*}{ ADHIII } & \multirow{2}{*}{$\begin{array}{c}\text { Mannitol } \\
\text { DH }\end{array}$} & \multirow[t]{2}{*}{ ADHII } & \multirow{2}{*}{$\begin{array}{c}\text { Cinnamyl } \\
\text { DHI }\end{array}$} & \multirow{2}{*}{$\begin{array}{l}\text { Propan-2- } \\
\text { ol DH }\end{array}$} & \multirow{2}{*}{$\begin{array}{c}\text { Cinnamyl } \\
\text { DHII }\end{array}$} & \multirow{2}{*}{$\begin{array}{c}\text { Pentan-2- } \\
\text { ol DH }\end{array}$} & \multirow{2}{*}{$\begin{array}{c}\text { Crotyl } \\
\text { DH }\end{array}$} & & \\
\hline & & & & & & & & & & $\begin{array}{c}\text { Glycerol } \\
\text { DHI }\end{array}$ & $\begin{array}{c}\text { Glycerol } \\
\text { DHII }\end{array}$ \\
\hline Methanol & + & - & - & + & - & - & - & - & - & - & - \\
\hline Ethanol & ++++ & \pm & - & ++ & - & - & - & - & - & - & ++ \\
\hline Propan-1-ol & $+++t$ & \pm or - & - & +++ & - & - & - & - & - & - & +++ \\
\hline Propan-2-ol & ++++ & + & - & \pm & - & + & - & \pm & - & - & - \\
\hline Butan-1-ol & $+t+$ & \pm & - & ++ & - & - & - & - & - & - & + \\
\hline Butan-2-ol & +++ & + & - & ++ & - & - & - & - & - & - & + \\
\hline Iso-butanol & ++ & + & - & ++ & - & - & - & - & - & - & + \\
\hline Pentan-2-ol & ++ & + & - & + & - & \pm & - & ++ & \pm or - & - & - \\
\hline Allyl alcohol & ++++ & + & - & +++ & - & - & - & - & - & - & ++ \\
\hline Glycerol & \pm & \pm or - & - & \pm & - & - & - & - & - & ++++ & ++ \\
\hline $\begin{array}{l}\text { Crotyl } \\
\text { alcohol }\end{array}$ & ++++ & + & - & +++ & + & - & - & - & \pm & - & + \\
\hline $\begin{array}{l}\text { Cinnamyl } \\
\text { alcohol }\end{array}$ & ++ & ++ & - & ++ & + & - & \pm & - & - & - & + \\
\hline Threonine & + & - & - & - & - & - & - & - & - & - & - \\
\hline 2,3-Butanediol & \pm or - & - & - & \pm & - & - & - & + & \pm & + & - \\
\hline 1,2-Propanediol & - & - & - & - & - & - & - & \pm & - & + & + \\
\hline Erythritol & \pm or - & - & - & \pm & - & - & - & - & - & ++ & \pm \\
\hline Mannitol & - & - & + & - & - & - & - & - & - & - & + \\
\hline
\end{tabular}

\section{Table 2. Induction/repression of ADHs in A. nidulans}

The concentration of the inducer/repressor used and the growth conditions for induction are detailed in Methods. The ability of a compound to act as an inducer/repressor was assessed from the staining ability in polyacrylamide gels of an extract made from mycelium grown in the presence of the compound ( + or - indicate the presence/absence of the enzyme under the stated conditions). The NAD ${ }^{+}$ dependent enzymes are listed in increasing order of mobility on the gel. Glycerol DHI has the same mobility as ADHII, and glycerol DHII has approximately the same mobility as cinnamyl DHI.

\begin{tabular}{|c|c|c|c|c|c|c|c|c|}
\hline & \multicolumn{8}{|c|}{ Inducer/repressor } \\
\hline & Ethanol & Fructose & Propan-2-ol & Pentan-2-ol & $\begin{array}{c}2,3- \\
\text { Butanediol }\end{array}$ & Glucose & $\begin{array}{c}\text { D- } \\
\text { Galacturonate }\end{array}$ & Anaerobiosis \\
\hline \multicolumn{9}{|c|}{$\begin{array}{l}\mathrm{NAD}^{+} \text {-dependent } \\
\text { enzyme }\end{array}$} \\
\hline ADHI & + & \pm & + & - & + & - & + & - \\
\hline ADHIII & - & - & - & - & - & - & - & + \\
\hline Mannitol DH & + & + & + & + & + & + & + & + \\
\hline ADHII & - & + & + & + & + & - & \pm & - \\
\hline Cinnamyl DHI & + & + & NT & + & + & - & NT & - \\
\hline Propan-2-ol DH & - & \pm & - & - & + & - & NT & - \\
\hline Cinnamyl DHII & - & + & NT & + & + & \pm & NT & - \\
\hline Pentan-2-ol DH & \pm & + & + & + & + & \pm & NT & \pm \\
\hline Crotyl DH & - & + & NT & + & + & - & NT & - \\
\hline \multicolumn{9}{|c|}{$\begin{array}{l}\text { NADP }^{+} \text {-dependent } \\
\text { enzyme }\end{array}$} \\
\hline Glycerol DHI & + & + & + & + & + & + & + & - \\
\hline Glycerol DHII & - & + & - & - & - & - & + & - \\
\hline
\end{tabular}

NT, Not tested. 


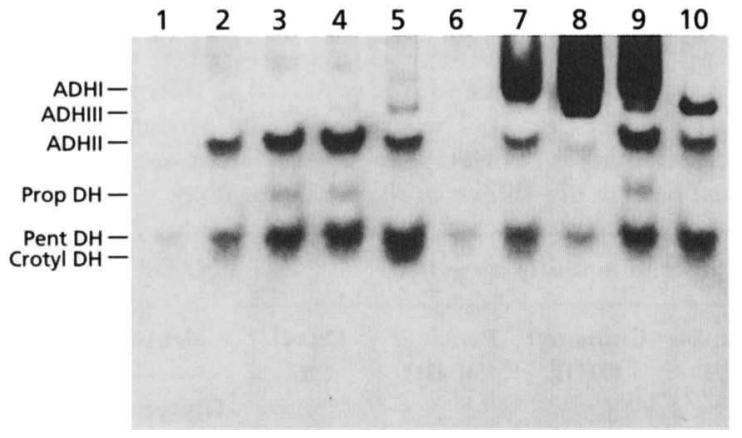

Fig. 2. ADH activity of extracts of the wild-type strain and $H 444$ carrying the alcR125 mutation on an activity stained gel. The staining solution contained $\mathrm{NAD}^{+}$and pentan-2-ol. All mycelia were grown for $16 \mathrm{~h}$ at $37^{\circ} \mathrm{C}$ on $1 \%$ glucose medium transferred for a further $6 \mathrm{~h}$ to various media. Tracks: $1-5$, H444; 6-10, wild-type. Tracks: 1, $50 \mathrm{mM}$ glucose; 2, $0.1 \%$ fructose; 3, $50 \mathrm{mM}$ 2,3-butanediol; 4, $100 \mathrm{mM}$ ethanol; 5, $50 \mathrm{mM}$ pentan-2-ol; $6,50 \mathrm{mM}$ glucose; $7,0.1 \%$ fructose; 8 , $100 \mathrm{mM}$ ethanol; 9, $50 \mathrm{mM}$ 2,3-butanediol; $10,50 \mathrm{mM}$ pentan2-ol. Each track contains $30 \mu \mathrm{g}$ protein. The enzymes are indicated on the left of the gel, and are abbreviated as in the legend to Fig. 1. These are representative gels and mycelia were grown up and run on gels at least twice. ADHIII was generally seen optimally after anaerobic transfer, but it was sometimes seen as above after growth at $37^{\circ} \mathrm{C}$. The propan-2-ol dehydrogenase is only a faint staining band and to see this band more clearly the gel was dried before photography. Under these conditions, above the ADHIII band in $\mathrm{H} 444$ additional faint bands can be seen, but normally these were so faint that they were not consistently visible, and they were excluded from the consideration of ADHs.

We have characterized their substrate specificity in the gel stain and given them names on the basis of that substrate which showed the greatest staining activity (Table 1). In all, six new $\mathrm{NAD}^{+}$-dependent ADHs were observed: mannitol, propan-2-ol, pentan-2-ol and crotyl dehydogenase, as well as two cinnamyl dehydrogenases. Of particular interest were propan-2-ol dehydrogenase and pentan-2-ol dehydrogenase; these were present under the same growth conditions as ADHII, i.e. these activities were observed on transfer to $0.1 \%$ fructose, and were repressed on transfer to ethanol or glucose. The inducibility of these enzymes on transfer to propan-2-ol, pentan-2-ol and 2,3-butanediol was also investigated since these alcohols were substrates for the enzyme(s) (Table 2).

\section{Propan-2-ol and pentan-2-ol dehydrogenase are under alCR control}

The wild-type strain was grown in parallel with strains H444, H1035 and H527 (see Methods). These strains were grown on glucose medium and then transferred to media containing $0.1 \%$ fructose, ethanol, propan-2-ol, 2,3butanediol, or glucose and anaerobic conditions. The wild-type strain shows induction of ADHI by ethanol, propan-2-ol and 2,3-butanediol. ADHII, propan-2-ol and 2,3-butanediol dehydrogenases were repressed by ethanol and propan-2-ol but not by 2,3- butanediol (Figs 2 and 3). We have previously reported (Sealy-Lewis \& Lockington,

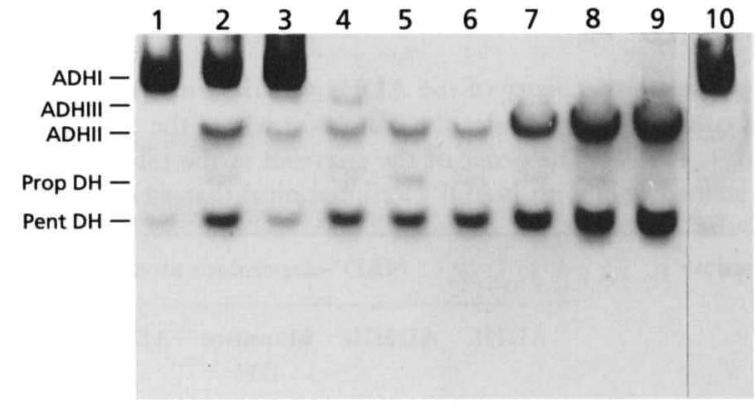

Fig. 3. ADH activity of extracts from the wild-type, H444 and H1035 on polyacrylamide gels. Tracks: $1-3$ and 10 , wild-type; 4-6, H444; 7-9 H1035. Mycelia were grown on $1 \%$ glucose for $16 \mathrm{~h}$ at $37^{\circ} \mathrm{C}$ and then transferred for a further $6 \mathrm{~h}$ to various media. Tracks: 1, $100 \mathrm{mM}$ ethanol; 2, $50 \mathrm{mM}$ 2,3-butanediol; 3, $100 \mathrm{mM}$ propan-2-ol; 4, $100 \mathrm{mM}$ ethanol; 5, $50 \mathrm{mM} \mathrm{2,3-}$ butanediol; 6, $100 \mathrm{mM}$ propan-2-ol; 7, $100 \mathrm{mM}$ ethanol; 8 , $50 \mathrm{mM} \mathrm{2,3-butanediol;} \mathrm{9,} 100 \mathrm{mM}$ propan-2-ol; 10, wild-type transferred to $50 \mathrm{mM}$ 2,3-butanediol. Tracks 1-9 were stained with $\mathrm{NAD}^{+}$and pentan-2-ol. Track 10 was stained with $\mathrm{NAD}^{+}$ and propan-2-ol. Each track contains $30 \mu \mathrm{g}$ protein. See legend to Fig. 1 for abbreviations.

1984) that in a strain carrying an alc $A^{-}$mutation, such as alc $A 527$, the ADHII enzyme is derepressed, and similarly propan-2-ol dehydrogenase and pentan-2-ol dehydrogenase show partial derepression in this mutant on transfer to ethanol medium (data not shown).

In the alcR 125 strain, ADHI is absent because ALCR is required for induction of ADHI, but ADHII, propan-2-ol dehydrogenase and 2,3-butanediol dehydrogenase are derepressed on ethanol and propan-2-ol (Fig. 3). In the alcE1; alc500 alcD1 strain, ADHII and pentan-2-ol dehydrogenase levels were elevated, but the level of propan2-ol dehydrogenase appeared to be unaffected (Fig. 3). ADHII, propan-2-ol dehydrogenase and pentan-2-ol dehydrogenase are all subject to the same negative control by ALCR , and in the case of pentan-2-ol dehydrogenase the alcD/alc $E$ mutations which result in elevated levels of ADHII also affect the level of this enzyme. ADHII and propan-2-ol dehydrogenase are completely repressed on transfer to glucose medium, and pentan-2-ol dehydrogenase is present at a low level during growth on glucose medium under both aerobic and, anaerobic conditions (Fig. 2).

\section{DISCUSSION}

ADHs have been widely studied in a variety of organisms, and it is common for there to be multiple ADHs within the same organism. There are at least four $\mathrm{ADHs}$ in Saccharomyces cerevisiae (Ciriacy, 1975; Williamson et al., 1980; Bennetzen \& Hall, 1982; Russell \& Hall, 1983; Young \& Pilgrim, 1985; Williamson \& Paquin, 1987). In $A$. nidulans, three $\mathrm{NAD}^{+}$-dependent ethanol dehydrogenases have previously been described. ADHI is the physiological enzyme of ethanol utilization, and ADHIII 
is produced under conditions of anaerobic stress. The function of ADHII has not been established, but it might be involved in de-toxification of acetaldehyde. In this paper we have demonstrated that in addition to these enzymes there is also a range of $\mathrm{ADHs}$ with distinct mobility in polyacrylamide gels, and different substrate specificity from the previously described enzymes. The staining reaction in polyacrylamide gels has allowed detection of very low levels of enzyme activity that would not be detectable in a conventional assay. Their normal role in metabolism is unknown. What is interesting is that at least two of these enzymes are under the same control as ADHII, i.e. they are repressed by ethanol in the wildtype strain, but are derepressed in an alc $\mathrm{R}^{-}$mutant strain. Propan-2-ol dehydrogenase, unlike ADHII and pentan-2ol dehydrogenase, is not induced by pentan-2-ol, and the level of this enzyme is not elevated in the alcE1; alc 500 alcD1 strain (H1035). The pentan-2-ol dehydrogenase, however, has the same profile of inducibility as ADHII and it is also elevated in the alcE1; alc 500 alcD 1 strain. The only difference between the two enzymes is that there is low activity of pentan-2-ol dehydrogenase on transfer to glucose or anaerobic glucose medium. It could be argued that this activity is encoded by the alcB gene and that it represents a differently processed form of the enzyme or, alternatively, pentan-2-ol dehydrogenase and ADHII represent a monomer and a dimer with different substrate specificity. Whether pentan-2-ol is encoded by a different gene from alcB could be resolved if we had a lack of function mutation in $\operatorname{alc} B$, but unfortunately, since the function of ADHII is unknown, we have been unable to select one. Now that the alc $B$ gene has been cloned, a gene inactivation of alcB will answer this question.

\section{ACKNOWLEDGEMENTS}

We thank the BBSRC for financial support.

\section{REFERENCES}

Bailey, C. \& Arst, H. N., Jr (1975). Carbon catabolite repression in Aspergillus nidulans. Eur J Biochem 51, 573-577.

Bennetzen, J. L. \& Hall, B. D. (1982). The primary structure of the Saccharomyces cerevisiae gene for alcohol dehydrogenase I. J Biol Chem 257, 3018-3025.

Ciriacy, M. (1975). Genetics of alcohol dehydrogenase in Saccharomyces cerevisiae. I. Isolation and genetic analysis of $\mathrm{ADH}$ mutants. Mutat Res 29, 315-326.

Clutterbuck, A. J. (1974). In Handbook of Genetics, pp. 447-510. Edited by R. C. King. New York: Plenum Press.

Cove, D. J. (1966). The induction and repression of nitrate reductase in the fungus, Aspergillus nidulans. Biochem Biophys Acta 113, 51-56.

Creaser, E. H., Porter, R. L., Brit, K. A., Pateman, J. A. \& Doy, C. H. (1985). Purification and preliminary characterization of alcohol dehydrogenase from Aspergillus nidulans. Biochem J 225, 449-454.

Felenbok, B. \& Sealy-Lewis, H. M. (1994). Alcohol metabolism. In Aspergillus: 50 Years on, pp. 141-179. Edited by S. D. Martinelli \& J. R. Kinghorn. Amsterdam: Elsevier.

Felenbok, B., Sequeval, D., Mathieu, M., Sibley, S., Gwynne, D. I. \& Davies, R. W. (1988). The ethanol regulon in Aspergillus nidulans: characterisation and sequence of the positive regulatory gene alc $R$. Gene 73, 385-396.

Felenbok, B., Sophianopoulou, V., Mathieu, M., Sequeval, D., Kulmburg, P., Diallinas, G. \& Scazzocchio, C. (1989). Regulation of genes involved in the utilization of carbon sources in Aspergillus nidulans. Found Biotech Ind Ferment Res Pub 6, 73-83.

Goa, J. (1953). A microbiuret method for protein determination. Determination of total protein in cerebrospinal fluid. Scand J Clin Lab Invest 5, 218-222.

Gwynne, D. I., Buxton, F. P., Sibley, S., Davies, R. W., Lockington, R. A., Scazzocchio, C. \& Sealy-Lewis, H. M. (1987). Comparison of the cis-acting control regions of two coordinately controlled genes involved in ethanol utilisation in Aspergillus nidulans. Gene 51, 205-216.

Hondmann, D. H. A., Busink, R., Witteveen, C. F. B. \& Visser, J. (1991). Glycerol catabolism in Aspergillus nidulans. J Gen Microbiol 137, 629-636.

Jones, I. G. \& Sealy-Lewis, H. M. (1989). Chromosomal mapping and gene disruption of the ADHIII gene in Aspergillus nidulans. Curr Genet 15, 135-142.

Kelly, J. M., Drysdale, M. R., Sealy-Lewis, H. M., Jones, I. G. \& Lockington, R. A. (1990). Alcohol dehydrogenase III in Aspergillus nidulans is anaerobically induced and post-transcriptionally regulated. Mol \& Gen Genet 222, 323-328.

Kulmburg, P., Prange, T., Mathieu, M., Sequeval, D., Scazzocchio, C. \& Felenbok, B. (1991). Correct intron splicing generates a new type of a putative zinc-binding domain in a transcriptional activator in Aspergillus nidulans. FEBS Lett 280, 11-16.

Lockington, R. A. (1984). Molecular investigations of the ribosomal $\mathrm{RN}$ A genes, and the ethanol utilisation genes of Aspergillus nidulans. $\mathrm{PhD}$ thesis, University of Essex.

Lockington, R. A., Scazzocchio, C., Sequeval, D., Mathieu, M. \& Felenbok, B. (1987). Regulation of alcR, the positive regulatory gene of the ethanol utilization regulon of Aspergillus nidulans. Mol Microbiol 1, 275-281.

McKnight, G. L., Kato, H., Upshall, A., Parker, M. D., Saari, G. \& O'Hara, P. J. (1985). Identification and molecular analysis of a third alcohol dehydrogenase in Aspergillus nidulans. EMBO $J$, 2093-2099.

Pateman, J. A., Doy, C. H., Olsen, J. E., Norris, U., Creaser, E. H. \& Hynes, M. J. (1983). Regulation of alcohol dehydrogenase (ADH) and aldehyde dehydrogenase (AldDH) in Aspergillus nidulans. Proc $\mathrm{R}$ Soc Lond B 217, 243-264.

Pickett, M., Gwynne, D. I., Buxton, F. P., Elliott, R., Davies, R. W., Lockington, R. A., Scazzocchio, C. \& Sealy-Lewis, H. M. (1987). Cloning and characterisation of the ald $A$ gene of Aspergillus nidulans. Gene 51, 217-222.

Roberts, T., Martinelli, S. D. \& Scazzocchio, C. (1979). Allele specific, gene unspecific suppressors in Aspergillus nidulans. Mol \& Gen Genet 177, 57-64.

Russell, P. R. \& Hall, B. D. (1983). The primary structure of the alcohol dehydrogenase gene from the fission yeast Schizosaccharomyces pombe. J Biol Chem 258, 143-149.

Sealy-Lewis, H. M. (1990). The identification of mutations in Aspergillus nidulans that lead to increased levels of ADHII. Curr Genet 18, 65-70.

Sealy-Lewis, H. M. \& Fairhurst, V. (1992). An NADP ${ }^{+}$-dependent glycerol dehydrogenase in Aspergillus nidulans is inducible by Dgalacturonate. Curr Genet 22, 293-296.

Sealy-Lewis, H. M. \& Lockington, R. A. (1984). Regulation of two alcohol dehydrogenases in Aspergillus nidulans. Curr Genet 8, 253-259. 
Williamson, V. M. \& Paquin, C. E. (1987). Homology of Saccharomyces cerevisiae $A D H 4$ to an iron-activated alcohol dehydrogenase from Zymomonas mobilis. Mol \& Gen Genet 209, 374-381.

Williamson, V. M., Bennetzen, J., Young, E. T., Nasmyth, K. \& Hall, B. (1980). Isolation of the structural gene for alcohol dehydrogenase by genetic complementation in yeast. Nature 283, 214-216.
Young, E. T. \& Pilgrim, D. (1985). Isolation and DNA sequence of $\mathrm{ADH} 3$, a nuclear gene encoding the mitochondrial isozyme of alcohol dehydrogenase in Saccharomyces cerevisiae. Mol Cell Biol 5, 3024-3034.

Received 29 March 1995; revised 22 May 1995; accepted 30 May 1995. 